\title{
Irreversibly Adsorbed Tri-metallic PtBiPd/C Electrocatalyst for the Efficient Formic Acid Oxidation Reaction
}

\author{
Lijun Sui ${ }^{1}$, Wei $\mathrm{An}^{2 *}$, Choong Kyun Rhee ${ }^{3 *}$, and Seung Hyun Hur ${ }^{1 *}$ \\ ${ }^{1}$ School of Chemical Engineering, University of Ulsan, Daehak-ro 93, Nam-gu, Ulsan 44610, Republic of Korea \\ ${ }^{2}$ College of Chemistry and Chemical Engineering, Shanghai University of Engineering Science, Songjiang District, Shanghai \\ 201620, China \\ ${ }^{3}$ Department of Chemistry, Chungnam National University, Daejeon 34314, Korea
}

\begin{abstract}
The $\mathrm{PtBi} / \mathrm{C}$ and $\mathrm{PtBiPd} / \mathrm{C}$ electrocatalysts were synthesized via the irreversible adsorption of $\mathrm{Pd}$ and $\mathrm{Bi}$ ions precursors on commercial $\mathrm{Pt} / \mathrm{C}$ catalysts. XRD and XPS revealed the formation of an alloy structure among $\mathrm{Pt}, \mathrm{Bi}$, and $\mathrm{Pd}$ atoms. The current of direct formic acid oxidation $\left(I_{d}\right)$ increased $\sim 8$ and 16 times for the $\mathrm{PtBi} / \mathrm{C}$ and $\mathrm{PtBiPd} / \mathrm{C}$ catalysts, respectively, than that of commercial Pt/C because of the electronic, geometric, and third body effects. In addition, the increased ratio between the current of direct formic acid oxidation $\left(I_{d}\right)$ and the current of indirect formic acid oxidation $\left(I_{\text {ind }}\right)$ for the PtBi/ $\mathrm{C}$ and $\mathrm{PtBiPd} / \mathrm{C}$ catalysts suggest that the dehydrogenation pathway is dominant with less $\mathrm{CO}$ formation on these catalysts.
\end{abstract}

Keywords: $\mathrm{HCOOH}$ Oxidation, Pt/C, Bismuth, Palladium, Irreversible Adsorption

Received : 16 September 2019, Accepted : 25 September 2019

\section{Introduction}

Direct formic acid fuel cells (DFAFCs) are considered promising alternative power sources for portable power devices because of their significant advantages, including high theoretical open circuit voltage $(1.45 \mathrm{~V})$, low crossover through the polymer membrane, high fuel concentration, low toxicity, and ambient temperature operability [1,2]. A wide range of sources of formic acid production have been mainly from fossil feedstock, but recently, biomass and $\mathrm{CO}_{2}$ hydrogenation have been studied extensively [3].

The electrocatalysts for both the anode and cathode electrodes are the most important factors affecting the final performance of DFAFCs, and Pt- and Pdbased catalysts have been studied widely because of their excellent catalytic activity and long term stability. In particular, $\mathrm{Pt}$ is considered the most

*E-mail address: shhur@ulsan.ac.kr (S.H. Hur), weian@sues.edu (Wei An), ckrhee@cnu.ac.kr (C.K. Rhee) DOI: https://doi.org/10.33961/jecst.2019.00556

This is an open-access article distributed under the terms of the Creative Commons Attribution Non-Commercial License (http://creativecommons.org/licenses/by-nc/4.0) Attribution Non-Commercial License (http://creativecommons.org/licenses/by-nc/4.0)
which permits unrestricted non-commercial use, distribution, and reproduction in any which permits unrestricted non-commercial use, distri
medium, provided the original work is properly cited. suitable electrocatalyst among all metals because of its excellent stability [4,5]. On the other hand, COpoisoning on the Pt surface by the dehydration pathway of $\mathrm{HCOOH}$ oxidation degrades its catalytic activity, which limits its use. The strong CO adsorption energy at low potential is responsible for the abundant $\mathrm{CO}$ adsorbed on the Pt surface [6,7]. The introduction of second metals, such as $\mathrm{Bi}$ [8], Ir [9], and $\mathrm{Ru}$ [10], can enhance the tolerance of $\mathrm{Pt}$ from $\mathrm{CO}$ poisoning by promoting $\mathrm{CO}_{2}$ formation directly or facilitating the $\mathrm{CO}$ oxidation reaction, which is due to either the synergistic catalytic effect or electronic structural effect.

Bismuth (Bi) is considered the most efficient modifier of the Pt catalyst for the $\mathrm{HCOOH}$ oxidation because of its third-body effect and electronic effect on the Pt surface [11-14]. Herrero et al. reported that Bi-modified Pt exhibited improved electrocatalytic activity and stability because of the synergistic effects of $\mathrm{Bi}$ in cleaving the $\mathrm{O}-\mathrm{H}$ bond and $\mathrm{Pt}$ causing $\mathrm{C}-\mathrm{H}$ bond scission [14]. In addition, Bi can promote the direct pathway (dehydrogenation) of $\mathrm{HCOOH}$, which can reduce the extent of $\mathrm{CO}$ poisoning of $\mathrm{Pt}$. On the other hand, $\mathrm{Bi}$ can be easily leached out from the electrode surface or oxidized to $\mathrm{Bi}_{2} \mathrm{O}_{3}$ at poten- 
tials over $0.8 \mathrm{~V}$ (vs. $\mathrm{Ag} / \mathrm{AgCl}$ ) in acid solution, which means that the Bi-modified Pt catalyst is so unstable when used at high potentials $[12,15]$. Recently, Ptbased tri-metal electrocatalysts, including PtPdAu [16], PtCuBi [17], and PtRuSn [18], have been studied widely to overcome such problems. Pd can be a good choice for the third element of the PtBi catalyst because $\mathrm{Pd}$ is very stable under acid conditions because of its stable electronic structure. In addition, BiPd [19,20], PdPt [21,22], and BiPt [13] catalysts could prevent the poisoning of $\mathrm{Pt}$ by $\mathrm{CO}$ due to the less CO chemisorption by the downshift of the dband center.

In this study, $\mathrm{PtBi} / \mathrm{C}$ and $\mathrm{PtBiPd} / \mathrm{C}$ electrocatalysts were synthesized by the irreversible adsorption of $\mathrm{Pd}$ and $\mathrm{Bi}$ on a $10 \mathrm{wt}$. \% commercial $\mathrm{Pt} / \mathrm{C}$ catalyst followed by the $\mathrm{NaBH}_{4}$ reduction. The irreversible adsorption is a simple preparation process that can avoid the complicated alloying procedures. In addition, alloy structures can be easily prepared without altering the bulk properties $[10,11]$. The introduction of $\mathrm{Bi}$ enhanced the direct formic acid oxidation over the indirect oxidation pathway. In addition, $\mathrm{Pd}$ increased the oxidation potential of $\mathrm{Bi}$ from 0.9 to $1.2 \mathrm{~V}$ (vs. $\mathrm{Ag} / \mathrm{AgCl}$ ), which resulted in highly improved electrocatalytic activity in $\mathrm{HCOOH}$ oxidation.

\section{Experimental}

\subsection{Catalyst synthesis}

The $\mathrm{PtBi} / \mathrm{C}$ and $\mathrm{PtBiPd} / \mathrm{C}$ electrocatalysts were synthesized by the irreversible adsorption of $\mathrm{Pd}$ and $\mathrm{Bi}$ ions to commercial $\mathrm{Pt} / \mathrm{C}$ followed by the reduction of metal ions. First, a $10 \mathrm{mM}$ Bi solution was prepared by dissolving bismuth oxide (SigmaAldrich, USA) with $20 \mathrm{ml}$ of $0.1 \mathrm{M} \mathrm{HClO}_{4}$. To synthesize the $\mathrm{PtBiPd} / \mathrm{C}$, mixed solutions of $10 \mathrm{mM}$ of $\mathrm{Bi}$ and $0.5 \mathrm{mM}$ of $\mathrm{Pd}$ ions were prepared by dissolving bismuth oxide and $\mathrm{Pd}\left(\mathrm{NO}_{3}\right)_{2}$ (SigmaAldrich, USA) with $20 \mathrm{~mL}$ of $0.1 \mathrm{M} \mathrm{HClO}_{4}$. The above solutions were kept at room temperature for 10 days to stabilize them. The irreversible adsorption of $\mathrm{Bi}$ ions or $\mathrm{Pd}$ and $\mathrm{Bi}$ ions was performed by adding $50 \mathrm{mg}$ of commercial 10 wt. \% Pt/C (Alfar Aesar, UK) to the above solutions with stirring (400 rpm) using a hotplate stirrer for 10 hours at $40^{\circ} \mathrm{C}$ and then were reduced by $0.019 \mathrm{M} \mathrm{NaBH}_{4}$ (Dae-Jung Chemicals \& Metals Co., Ltd, Korea) for $30 \mathrm{~min}$. It was washed several times with $0.1 \mathrm{M} \mathrm{HClO}_{4}$ solution followed by a drying at $70^{\circ} \mathrm{C}$ for $3 \mathrm{~h}$ in a vacuum oven.

\subsection{Instrumental analysis}

X-ray diffraction (XRD PANalytical X'Pert Pro MPD, Malvern Panalytical, USA) of the commercial $\mathrm{Pt} / \mathrm{C}, \mathrm{PtBi} / \mathrm{C}$, and $\mathrm{PtBiPd} / \mathrm{C}$ was performed using $40 \mathrm{kV} \mathrm{Cu} \mathrm{K \alpha}$ radiation. The scanning rate and $2 \theta$ range was $10^{\circ} / \mathrm{min}$ and $0-100^{\circ}$, respectively. The morphology was examined by high-resolution transmission electron microscopy (HR-TEM, JEOL JEM2100F, USA). X-ray photoelectron spectroscopy (XPS, ESCALAB 250Xi Thermo Fisher Scientific, USA) was performed using an $\mathrm{Al} \mathrm{K} \alpha \mathrm{X}$-ray source. Cyclic voltammetry (CV) was recorded on a SP-50 (Bio-Logic, USA).

\subsection{Electrochemical evaluation}

Catalyst ink was prepared by mixing $0.5 \mathrm{mg}$ of catalyst powder with $1 \mathrm{ml}$ of ethanol and $1 \mathrm{mg}$ of Nafion (5 wt. \%, Sigma-Aldrich, USA). After $30 \mathrm{~min}$ sonication, $10 \mu \mathrm{L}$ of the paste was spread on the GC electrode with a micropipette and dried using a hot air drier for $15 \mathrm{~min}$.

Electrochemical tests were conducted at room temperature in a three-electrode-system using an Ag/ $\mathrm{AgCl}$ (sat. $\mathrm{KCl}$ ) reference electrode and a $\mathrm{Pt}$ wire counter electrode. $\mathrm{H}_{2} \mathrm{SO}_{4}(0.5 \mathrm{M})$ was used as an electrolyte solution and the electrode was subjected to potential cycling from $-0.2 \mathrm{~V}$ to $1.2 \mathrm{~V}$ with a $10 \mathrm{mVs}^{-1}$ scan rate. The $0.1 \mathrm{M}$ formic acid oxidation was performed in $0.5 \mathrm{M} \mathrm{H}_{2} \mathrm{SO}_{4}$ with potential cycling from $-0.25 \mathrm{~V}$ to $1.2 \mathrm{~V}$ at $20 \mathrm{mVs}^{-1}$ scan rate.

\section{Results and Discussion}

As shown in Fig. 1 and summarized in Table 1, the metal nanoparticles were anchored evenly over the carbon support and the particle size $\mathrm{Pt} / \mathrm{C}$ did not change significantly after the irreversible adsorption of $\mathrm{Bi}$, or $\mathrm{Pd}$ and $\mathrm{Bi}$, which suggests that $\mathrm{Pd}$ and $\mathrm{Bi}$ are only slightly adsorbed on the Pt surface.

Fig. 2 presents XRD patterns of the $\mathrm{Pt} / \mathrm{C}, \mathrm{PtBi} / \mathrm{C}$, and $\mathrm{PtBiPd} / \mathrm{C}$. The broad XRD peaks at approximately $2 \theta=40,46,67$, and $80^{\circ}$ were assigned to the Pt(111), (200), (220), and (311) planes, respectively. The XRD patterns of $\mathrm{PtBi} / \mathrm{C}$ were similar because the characteristic peaks of $\mathrm{Bi}$ almost overlapped with 

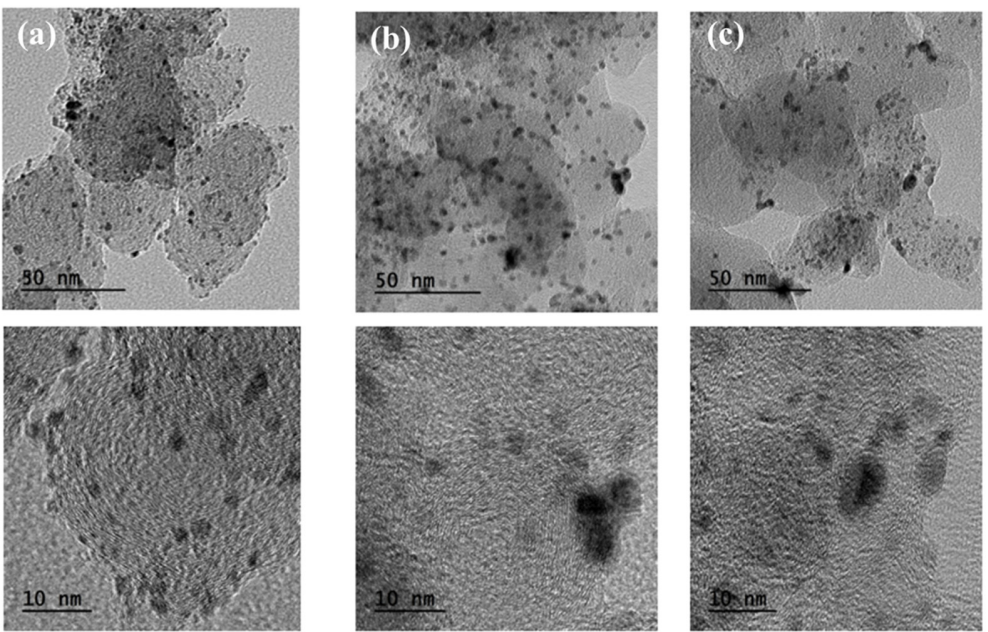

Fig. 1. TEM images of (a)Pt/C, (b)PtBi/C and (c)PtBiPd/C.

Table 1. Particle size of metal nanoparticles in the $\mathrm{Pt} / \mathrm{C}$, $\mathrm{BiPt} / \mathrm{C}$ and $\mathrm{PdBiPt} / \mathrm{C}$.

\begin{tabular}{cc}
\hline \hline Catalyst & Particle size $(\mathrm{nm})$ \\
\hline $\mathrm{Pt} / \mathrm{C}$ & $2.5 \pm 0.5$ \\
$\mathrm{PtBi} / \mathrm{C}$ & $2.8 \pm 0.4$ \\
$\mathrm{PtBiPd} / \mathrm{C}$ & $2.4 \pm 0.8$ \\
\hline
\end{tabular}

those of Pt. On the other hand, the peak broadening suggests that a PtBi alloy is formed and partial $\mathrm{Bi}$ atoms incorporate into the Pt crystal lattice. In addition, when the $\mathrm{Pd}$ and $\mathrm{Bi}$ are co-adsorbed on the $\mathrm{Pt} / \mathrm{C}$, three small peaks are observed, corresponding to $\mathrm{BiPt}$, and the second peak is consistent with $\mathrm{Bi}_{2} \mathrm{Pd}$
(Fig. 2b) $[20,23]$. The lattice parameters of the catalysts were calculated based on Bragg's law and the Scherrer formula using the (111) XRD peak, as summarized in Table 2.

The lattice constant of the $\mathrm{PtBi} / \mathrm{C}$ was larger than that of $\mathrm{Pt} / \mathrm{C}$ because of the larger atomic size of $\mathrm{Bi}$ than Pt. Similarly, the smaller lattice constant of PdBiPt/C than that of $\mathrm{PtBi} / \mathrm{C}$ can be due to the smaller atomic size of $\mathrm{Pd}$ than $\mathrm{Pt}$ and $\mathrm{Bi}$. The variations of the lattice constant and crystallite size of various catalysts suggest the formation of alloy structures in the $\mathrm{PtBi} / \mathrm{C}$ and $\mathrm{PdBiPt} / \mathrm{C}$ catalysts [24].

XPS was performed to examine the chemical structures of various catalysts. As shown in the XPS survey spectra of Fig. 3, Pt, Bi, and C peaks except
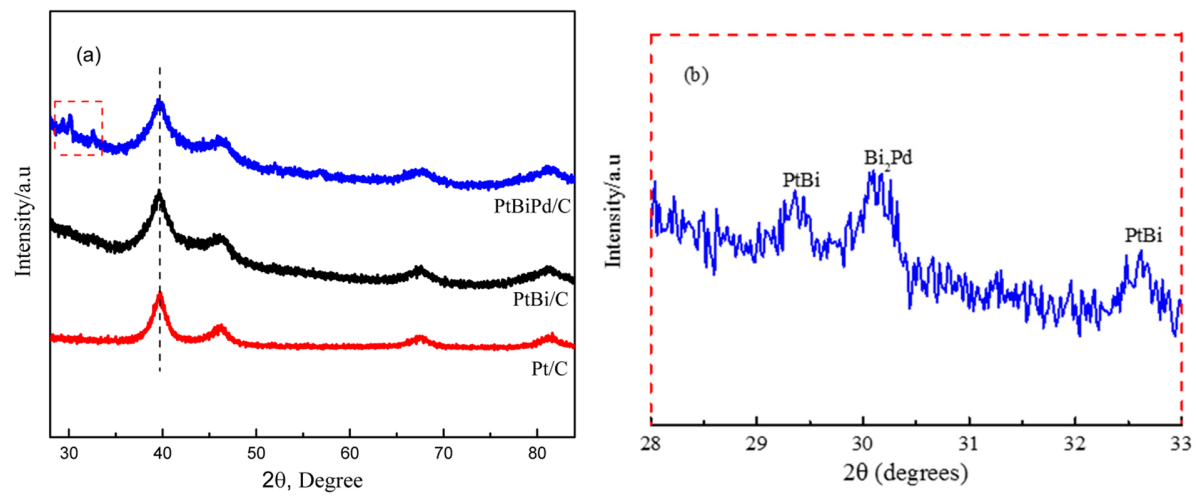

Fig. 2. (a) XRD patterns of Pt/C, PtBi/C, PtBiPd/C. (b) Enlarged XRD pattern of the red box of (a). 
Table 2. Crystalline sizes and lattice constants of the various catalysts based on XRD.

\begin{tabular}{ccc}
\hline \hline Sample & $\begin{array}{c}\text { Crystalline size } \\
(\mathrm{nm})\end{array}$ & $\begin{array}{c}\text { Lattice constant } \\
(\AA)\end{array}$ \\
\hline $\mathrm{Pt} / \mathrm{C}$ & 5.8 & 3.936 \\
$\mathrm{PtBi} / \mathrm{C}$ & 3.5 & 4.058 \\
$\mathrm{PtBiPd} / \mathrm{C}$ & 3.4 & 3.983 \\
\hline
\end{tabular}
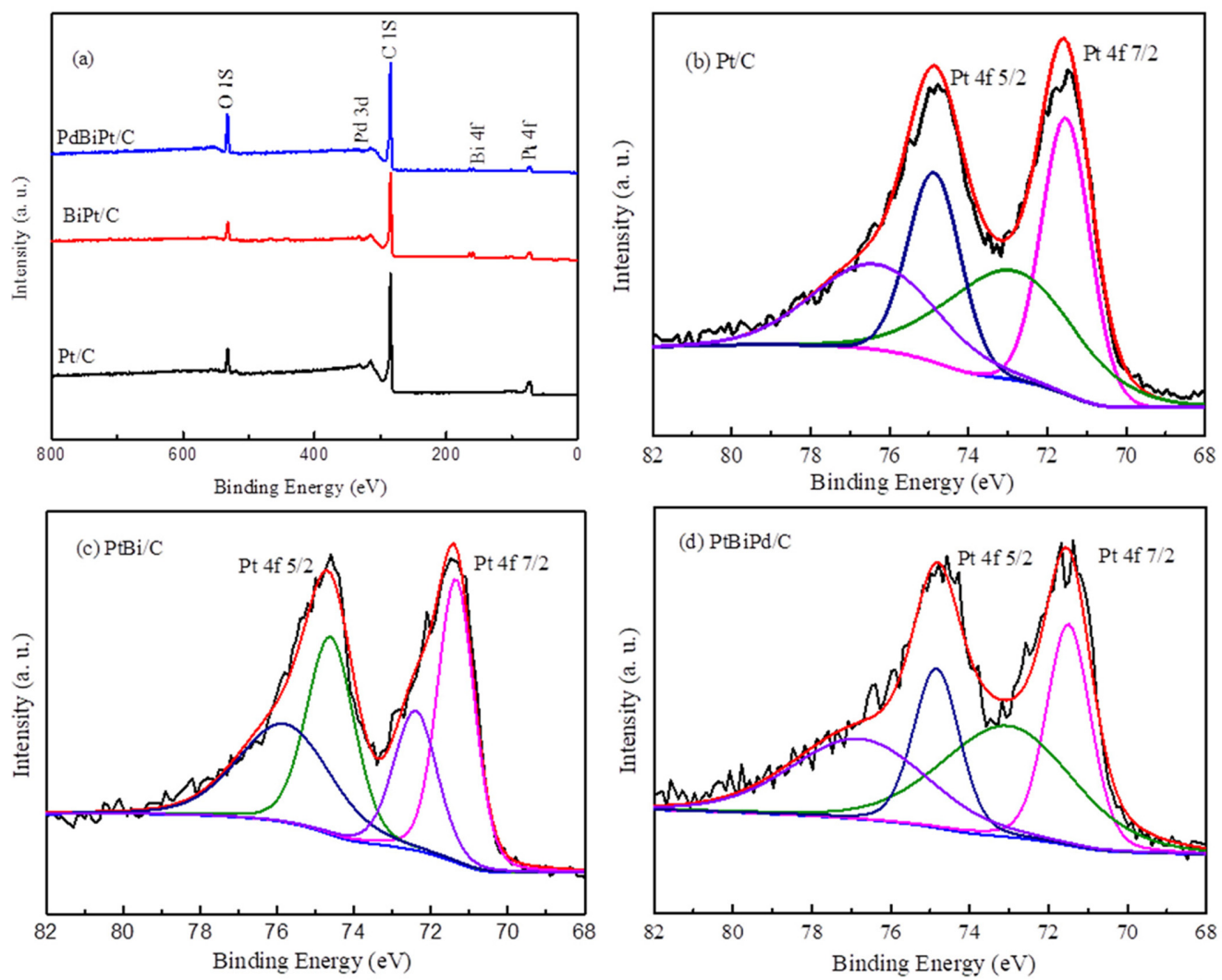

Pere observed in each corresponding catalyst. Generally, it is very difficult to observe the Pd peak, particularly when the content is very small because its position overlaps with those of $\mathrm{Pt}$ and $\mathrm{C}$. As shown in Figs. $4 \mathrm{~b}-4 \mathrm{~d}$, the $\mathrm{Pt} 4 \mathrm{f}_{7 / 2}$ peak can be deconvoluted to two sub-peaks at approximately 71.5 and $72.9 \mathrm{eV}$, corresponding to $\mathrm{Pt}(0)$ and $\mathrm{Pt}(\mathrm{II})$, respectively [25]. The Bi $4 \mathrm{f}_{7 / 2}$ also can be deconvoluted into
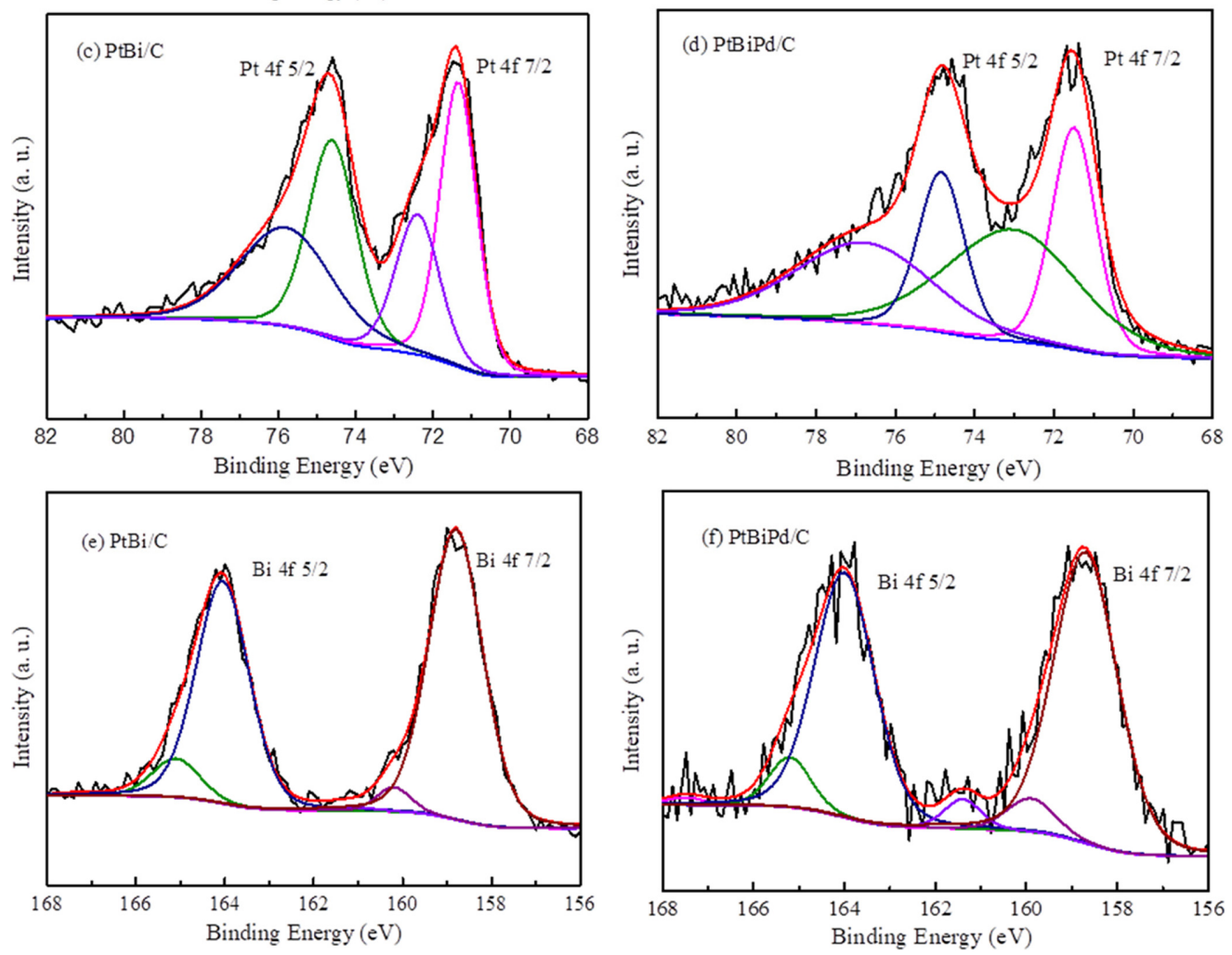

Fig. 3. (a) XPS survey spectra of $\mathrm{Pt} / \mathrm{C}, \mathrm{PtBi} / \mathrm{C}$ and $\mathrm{PtBiPd} / \mathrm{C}$. High resolution XPS Pt $4 \mathrm{f}$ spectra of (b) $\mathrm{Pt} / \mathrm{C}$, (c) $\mathrm{PtBi} / \mathrm{C}$ and (d) $\mathrm{PtBiPd} / \mathrm{C}$. High resolution XPS Bi 4f spectra of (e) $\mathrm{PtBi} / \mathrm{C}$ and (f) $\mathrm{PtBiPd} / \mathrm{C}$. 

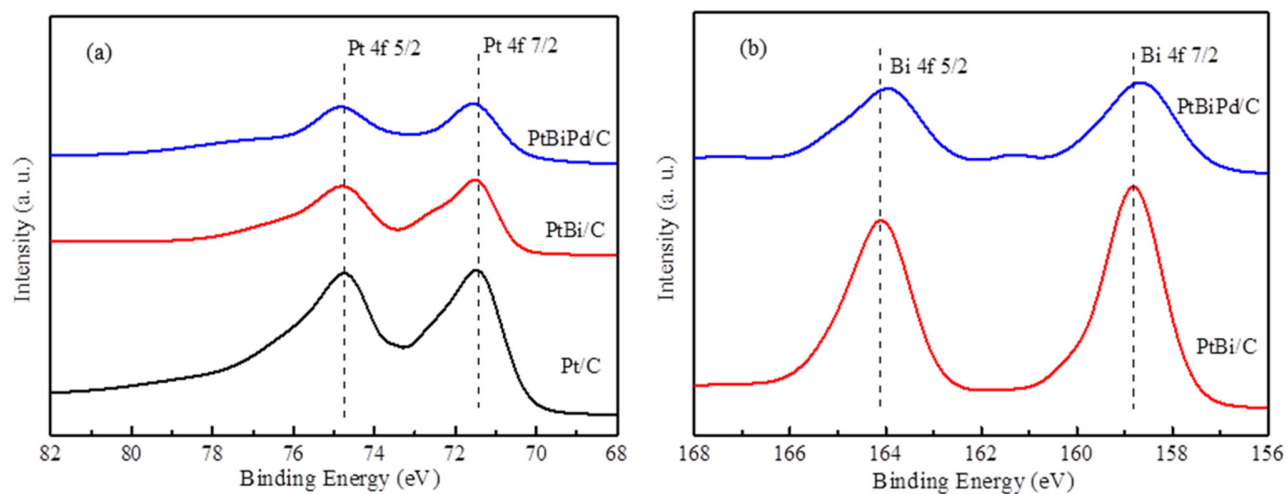

Fig. 4. (a) High resolution Pt 4f XPS peaks of various catalysts. (b) High resolution Bi $4 \mathrm{f}$ XPS peaks of various catalysts.

Table 3. Binding energies and relative intensities of the different chemical states of $\mathrm{Pt} 4 \mathrm{f}_{7 / 2}$ and $\mathrm{Bi} 4 \mathrm{f}_{7 / 2}$ in the $\mathrm{Pt} / \mathrm{C}$, $\mathrm{PtBi} / \mathrm{C}$ and $\mathrm{PtBiPd} / \mathrm{C}$ catalysts.

\begin{tabular}{cccc}
\hline \hline Sample & Species & $\begin{array}{c}\text { Binging energy Relative intensity } \\
(\mathrm{eV})\end{array}$ & $\begin{array}{c}\text { (\%) } \\
\text { Pt/C }\end{array}$ \\
& $\mathrm{Pt}(0)$ & 71.5 & 51 \\
& $\mathrm{Pt}(\mathrm{II})$ & 72.9 & 49 \\
& $\mathrm{Pt}(0)$ & 71.4 & 57 \\
$\mathrm{PtBi} / \mathrm{C}$ & $\mathrm{Pt}(\mathrm{II})$ & 72.4 & 43 \\
& $\mathrm{Bi}(0)$ & 158.8 & 91 \\
& $\mathrm{Bi}(\mathrm{III})$ & 160.2 & 9 \\
& $\mathrm{Pt}(0)$ & 71.5 & 40 \\
$\mathrm{PtBiPd} / \mathrm{C}$ & $\mathrm{Pt}(\mathrm{II})$ & 73.1 & 60 \\
& $\mathrm{Bi}(0)$ & 158.7 & 90 \\
& $\mathrm{Bi}(\mathrm{III})$ & 160.0 & 10 \\
\hline
\end{tabular}

two sub-peaks at approximately 158 and $160 \mathrm{eV}$, which correspond to $\mathrm{Bi}(0)$ and $\mathrm{Bi}(\mathrm{III})$, respectively [26]. As summarized in Table 3, $\mathrm{Bi}(0)$ is dominant in both $\mathrm{PtBi} / \mathrm{C}$ and $\mathrm{PtBiPd} / \mathrm{C}$, which indicates that $\mathrm{Bi}_{2} \mathrm{O}_{3}$ was almost reduced to $\mathrm{Bi}$. Therefore, metallic $\mathrm{Bi}$ can be dominant on the catalyst surface. Interestingly, the Pt $4 \mathrm{f}$ peak shifted slightly toward a higher binding energy, as shown in Fig. 4(a), indicating the formation of an alloy structure between Pt and Bi. Similarly, the peak shift of $\mathrm{Bi} 4 \mathrm{f}$ to a lower binding energy indicated the formation of an alloy structure between $\mathrm{Pd}$ and $\mathrm{Bi}$, as shown in Fig. 4(b) [27].

The electrochemical performance was examined by $\mathrm{CV}$. As shown in Fig. 5, the hydrogen region below $0.0 \mathrm{~V}$ and $\mathrm{Pt}$ oxidation/reduction peak at $\sim 0.8$

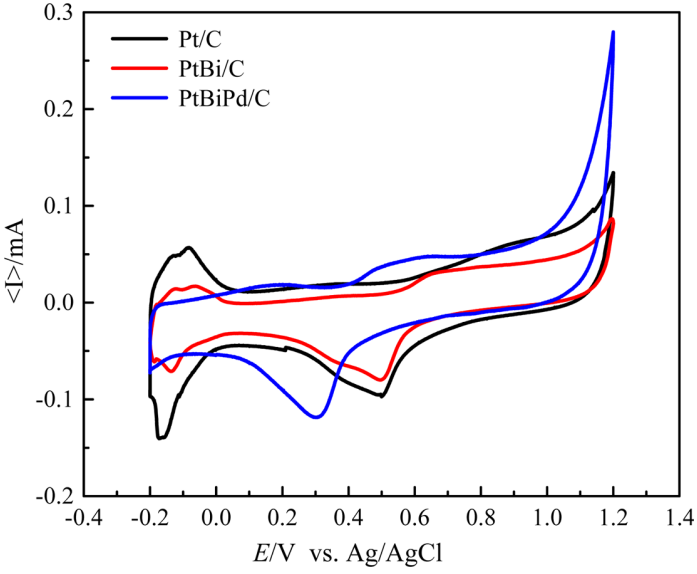

Fig. 5. $\mathrm{CV}$ of $\mathrm{Pt} / \mathrm{C}, \mathrm{PtBi} / \mathrm{C}$ and $\mathrm{PtBiPd} / \mathrm{C}\left(0.5 \mathrm{M} \mathrm{H}_{2} \mathrm{SO}_{4}\right.$, scan rate $=10 \mathrm{mV} / \mathrm{s}$ ).

and $\sim 0.5 \mathrm{~V}$ were observed clearly for the $\mathrm{Pt} / \mathrm{C}$ catalyst. When $\mathrm{Bi}$ was adsorbed on the $\mathrm{Pt} / \mathrm{C}$ catalyst, the current related to the hydrogen region and $\mathrm{Pt}$ oxidation/reduction decreased because $\mathrm{Bi}$ atoms cover the $\mathrm{Pt}$ sites. The $\mathrm{PtBiPd} / \mathrm{C}$ catalyst showed a further decrease in the current of the hydrogen region and a shift of the reduction potential to a lower potential than that of $\mathrm{BiPt} / \mathrm{C}$, which indicates alloy formation in the $\mathrm{PdBiPt} / \mathrm{C}$.

The formic acid oxidation reaction was performed using a range of catalysts in a $2 \mathrm{M} \mathrm{HCOOH}$ and $0.5 \mathrm{M} \mathrm{H}_{2} \mathrm{SO}_{4}$ solution. Generally, formic acid is oxidized to $\mathrm{CO}_{2}$ via two pathways [1].

i) Direct oxidation pathway (dehydrogenation) $\mathrm{HCOOH} \rightarrow \mathrm{CO}_{2}+2 \mathrm{H}^{+}+2 \mathrm{e}^{-}$ 

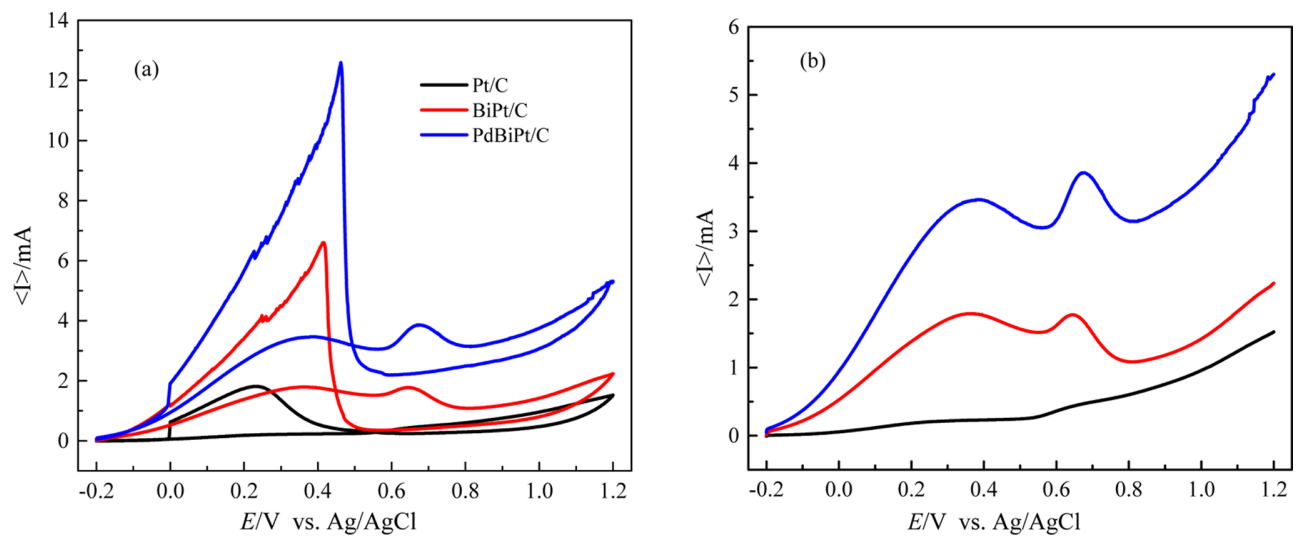

Fig. 6. (a) $\mathrm{CV}$ obtained at $\mathrm{Pt} / \mathrm{C}, \mathrm{PtBi} / \mathrm{C}$ and $\mathrm{PtBiPd} / \mathrm{C}$ catalysts. (b) Forward scan of formic acid oxidation on the different catalysts. The solution contains $0.5 \mathrm{M} \mathrm{H}_{2} \mathrm{SO}_{4}$ and $2 \mathrm{M} \mathrm{HCOOH}$. The scan rate was $20 \mathrm{mV} / \mathrm{s}$.

Table 4. Formic acid oxidation current of various catalysts.

\begin{tabular}{ccccc}
\hline \hline Sample & First Peak $\left(\mathrm{I}_{\mathrm{d}}\right)(\mathrm{mA})$ & Second Peak $\left(\mathrm{I}_{\text {ind }}\right)(\mathrm{mA})$ & Reverse scan peak $(\mathrm{mA})$ & $\mathrm{I}_{\mathrm{d}} / \mathrm{I}_{\text {ind }}$ \\
\hline $\mathrm{Pt} / \mathrm{C}$ & 0.21 & 0.45 & 1.80 & 0.46 \\
$10 \mathrm{mM} \mathrm{PtBi} / \mathrm{C}$ & 1.78 & 1.77 & 6.59 & 1.01 \\
$0.5 \mathrm{mM} \mathrm{PtBiPd} / \mathrm{C}$ & 3.46 & 3.85 & 12.59 & 0.89 \\
\hline
\end{tabular}

Table 5. The comparison of formic acid oxidation peak current for the various catalysts.

\begin{tabular}{cccc}
\hline \hline & $\begin{array}{c}\mathrm{PtBiPd} / \mathrm{C} \\
\text { This work }\end{array}$ & $\begin{array}{c}\mathrm{PtPdAu} / \mathrm{C} \\
\operatorname{Ref}[16]\end{array}$ & $\begin{array}{c}\mathrm{Pt}_{1} \mathrm{Pd}_{3} \mathrm{Cu}_{3} / \mathrm{C} \\
\operatorname{Ref}^{2}[17]\end{array}$ \\
\hline $\mathrm{I}(\mathrm{Pt} / \mathrm{C}), \mathrm{mA}$ & 0.21 & 0.50 & 0.17 \\
$\mathrm{I}(\mathrm{PtMN} / \mathrm{C})^{*}, \mathrm{~mA}$ & 3.46 & 1.30 & 1.16 \\
$\mathrm{I}(\mathrm{PtMN} / \mathrm{C}) / \mathrm{I}(\mathrm{Pt} / \mathrm{C})$ & 16 & 3 & 7 \\
\hline
\end{tabular}

"M and $\mathrm{N}$ indicate other metals.

ii) Indirect oxidation pathway (dehydration, poisoning)

$\mathrm{HCOOH} \rightarrow \mathrm{CO}_{\text {ads }}+\mathrm{H}_{2} \mathrm{O}$

$\mathrm{CO}_{\mathrm{ads}}+\mathrm{H}_{2} \mathrm{O} \rightarrow \mathrm{CO}_{2}+2 \mathrm{H}^{+}+2 \mathrm{e}^{-}$

As shown in Fig. 6, two oxidation peaks in the positive scan were observed, which correspond to the direct and indirect oxidation reaction pathways. The commercial $\mathrm{Pt} / \mathrm{C}$ catalyst showed poor formic acid oxidation activity due to $\mathrm{CO}$ poisoning by the formation of $\mathrm{CO}_{\mathrm{ads}}$ on the Pt surface. Instead, the $\mathrm{PtBi} / \mathrm{C}$ and $\mathrm{PtBiPd} / \mathrm{C}$ catalysts exhibited enhanced electrocatalytic activity. As summarized in Tables 4 and 5, the current of direct formic acid oxidation $\left(I_{d}\right)$ increased $\sim 8$ and 16 folds for the $\mathrm{PtBi} / \mathrm{C}$ and $\mathrm{PtBiPd} /$ $\mathrm{C}$ catalysts compared to that of commercial $\mathrm{Pt} / \mathrm{C}$ because of the electronic, geometric, and third body effects [20,27], which are higher values than those of previous studies $[16,17]$. In addition, the higher ratio between $I_{d}$ and the current of indirect formic acid oxidation $\left(I_{\text {ind }}\right)$ for the $\mathrm{PtBi} / \mathrm{C}$ and $\mathrm{PtBiPd} / \mathrm{C}$ catalysts indicates that the dehydrogenation pathway is dominant with less $\mathrm{CO}$ formation on these catalysts.

To examine the effects of $\mathrm{Pd}$ on formic acid oxidation, the scan range was varied, especially for the upper potential limit (UPL), because it can affect the reverse scan peak by the leaching of metal at high potential. As shown in Fig. 7(a), in the case of the $\mathrm{PtBi} / \mathrm{C}$ catalyst, the maximum current of reverse scan increases initially with increasing UPL because of the oxidation of the $\mathrm{CO}_{\text {ads }}$ at high potential. The reverse 

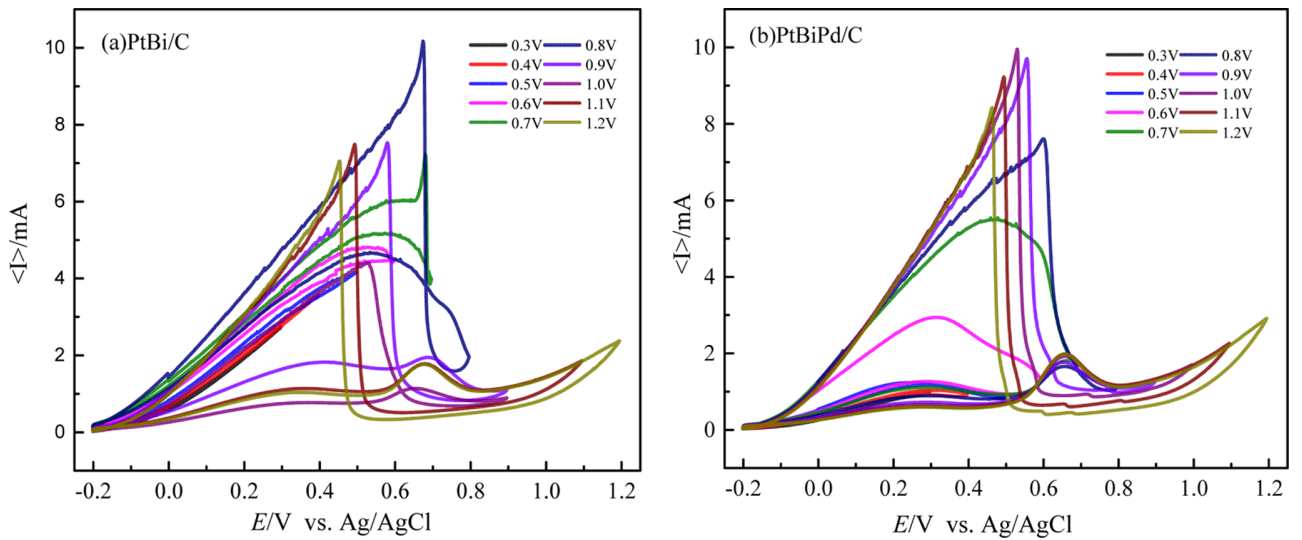

Fig. 7. $\mathrm{CV}$ obtained at (a) $\mathrm{BiPt} / \mathrm{C}$ and (b) $\mathrm{Pt} / \mathrm{BiPd} / \mathrm{C}$ catalysts. The voltage was swept from -0.20 to $1.2 \mathrm{~V}$ with an increasing step of $0.1 \mathrm{~V}$. The solution contained $0.5 \mathrm{M} \mathrm{H}_{2} \mathrm{SO}_{4}$ and $2 \mathrm{M} \mathrm{HCOOH}$. The scan rate was $20 \mathrm{mV} / \mathrm{s}$.

scan current was highest when the UPL was $0.8 \mathrm{~V}$ and decreased from $0.9 \mathrm{~V}$, which is due to Bi leaching out at high potential $[21,23,24]$. Instead, in the case of the $\mathrm{PtBiPd} / \mathrm{C}$ catalyst, the maximum reverse scan current was highest at $1.1 \mathrm{~V}$ of the UPL, which means that $\mathrm{Bi}$ leaching occurs at a higher potential than that of the $\mathrm{PtBi} / \mathrm{C}$ catalyst by the co-adsorbed $\mathrm{Pd}$ [29], which can be attributed to the formation of the PdBi alloy structure that has a strong resistance against Bi leaching [30].

\section{Conclusions}

$\mathrm{PtBi} / \mathrm{C}$ and $\mathrm{PtBiPd} / \mathrm{C}$ catalysts were synthesized by the irreversible adsorption of $\mathrm{Pd}$ and $\mathrm{Bi}$ using $\mathrm{Bi}_{2} \mathrm{O}_{3}$, $\mathrm{Pd}\left(\mathrm{NO}_{3}\right)_{2}$ as precursors on commercial $\mathrm{Pt} / \mathrm{C}$ followed by $\mathrm{NaBH}_{4}$ reduction. Instrumental analysis showed that the alloy structure was formed among $\mathrm{Pt}, \mathrm{Bi}$, and $\mathrm{Pd}$. The $\mathrm{Bi}$ atoms enhanced the direct formic acid oxidation reaction and $\mathrm{Pd}$ atoms improved the resistance against $\mathrm{Bi}$ bleaching at high potential, which strongly improved the overall formic oxidation reaction.

\section{Acknowledgment}

This study was supported by the Basic Science Research Program through the National Research Foundation of Korea (NRF) funded by The Ministry of Science, ICT and Future Planning (2019R1A2B5B0206 9683).

\section{References}

[1] C. Rice, S. Ha, R.I. Masel, P. Waszczuk, A.Wieckowski and T. Barnard, J. Power Sources 2002, 111, 83-89.

[2] B. C. Ong, S. K. Kamarudin and S. Basri, Int. J. Hydrogen Energy 2017, 42, 10142-10157.

[3] M. Grasemann and G. Laurenczy, Energy Environ. Sci. 2012, 5, 8171-8181.

[4] P. Hong, F. Luo, S. Liao and J. Zeng, Int. J. Hydrogen Energy 2011, 36, 8518-8524.

[5] K. Jiang, H. X. Zhang, S. Zou and W. B. Cai, PCCP 2014, 16, 20360-20376.

[6] W. Gao, J. A. Keith, J. Anton and T. Jacob, JACS 2010, 132, 18377-18385.

[7] E. Herrero and J. M. Feliu, Curr. Opin. Electrochem. 2018, 9, 145-150.

[8] J. K. Yoo, M. Choi, S. Yang, B. Shong, H.-S. Chung, Y. Sohn and C. K. Rhee, Electrochim. Acta 2018, 273, 307317.

[9] W. Chen and S. Chen, J. Mater. Chem. A 2011, 21, 9169-9178.

[10] E. N. El Sawy and P. G. Pickup, Electrocatalysis 2016, 7, 477-448.

[11] M. Choi, C.-Y. Ahn, H. Lee, J. K. Kim, S.-H. Oh, W. Hwang, S. Yang, J. Kim, O.-H. Kim, I. Choi, Y.-E. Sung, Y.-H. Cho, C. K. Rhee and W. Shin, Appl. Catal., B 2019, 253, 187-195.

[12] J. D. Lović, S. I. Stevanović, D. V. Tripković, A. V. Tripković, R. M. Stevanović, V. M. Jovanović and K. D. Popović, J. Solid State Electrochem. 2015, 19, 22232233.

[13] X. Yuan, X. Jiang, M. Cao, L. Chen, K. Nie, Y. Zhang, Y. Xu, X. Sun, Y. Li and Q. Zhang, Nano Res. 2019, 12, 429-436.

[14] J. V. Perales-Rondon, A. Ferre-Vilaplana, J. M. Feliu and E. Herrero, JACS 2014, 136, 13110-13113.

[15] D. R. Blasini, D. Rochefort, E. Fachini, L. R. Alden, F. 
J. DiSalvo, C. R. Cabrera and H. D. Abruña, Surf. Sci. 2006, 600, 2670-2680.

[16] C. Li, H. Wang, Y. Li, H. Yu, S. Yin, H. Xue, X. Li, Y. $\mathrm{Xu}$ and L. Wang, J. Nanotechnol. 2018, 29, $11762-$ 117625.

[17] M. A. Ud Din, F. Saleem, B. Ni, Y. Yong and X. Wang, Adv. Mater. 2017, 1604994, 1-8.

[18] J. S. Yoo, H. T. Kim, H.-I. Joh, H. Kim and S. H. Moon, Int. J. Hydrogen Energy 2011, 36, 1930-1938.

[19] R. W. Atkinson, S. St. John, O. Dyck, K. A. Unocic, R. R. Unocic, C. S. Burke, J. W. Cisco, C. A. Rice, T. A. Zawodzinski and A. B. Papandrew, A. B., ACS Catal. 2015, 5, 5154-5163.

[20] H. Xu, B. Yan, K. Zhang, J. Wang, S. Li, C. Wang, Y. Du, P. Yang, S. Jiang and S. Song, Appl. Surf. Sci. 2017, 416, 191-199.

[21] H.-X. Zhang, C. Wang, J.-Y. Wang, J.-J. Zhai and W.-B.
Cai, J. Phys. Chem. C 2010, 114, 6446-6451.

[22] B. Gralec and A. Lewera, Appl. Catal., B 2016, 192, 304-310.

[23] H. Liao, J. Zhu and Y. Hou, Nanoscale 2014, 6, 10491055.

[24] Y. Suo, Int. J. Electrochem. Sci. 2017, 12, 3561-3575.

[25] J.-N. Zheng, J.-J. Lv, S.-S. Li, M.-W. Xue, A.-J. Wang and J.-J. Feng, JACS 2014, 2, 3445-3451.

[26] A. Zalineeva, A. Serov, M. Padilla, U. Martinez, K. Artyushkova, S. Baranton, C. Coutanceau and P. B. Atanassov, JACS 2014, 136, 3937-3945.

[27] P. Kiatkittikul, J. Yamaguchi, T. Nohira and R. Hagiwara, Electrochemistry 2016, 84, 766-768.

[28] F. Alardin, P. Ruiz, B. Delmon and M. Devillers, Appl. Catal., A 2001, 215, 125-136.

[29] M. Besson, F. Lahmer, P. Gallezot, P. Fuertes and G. Fleche, J. Catal. 1995, 152, 116-121. 